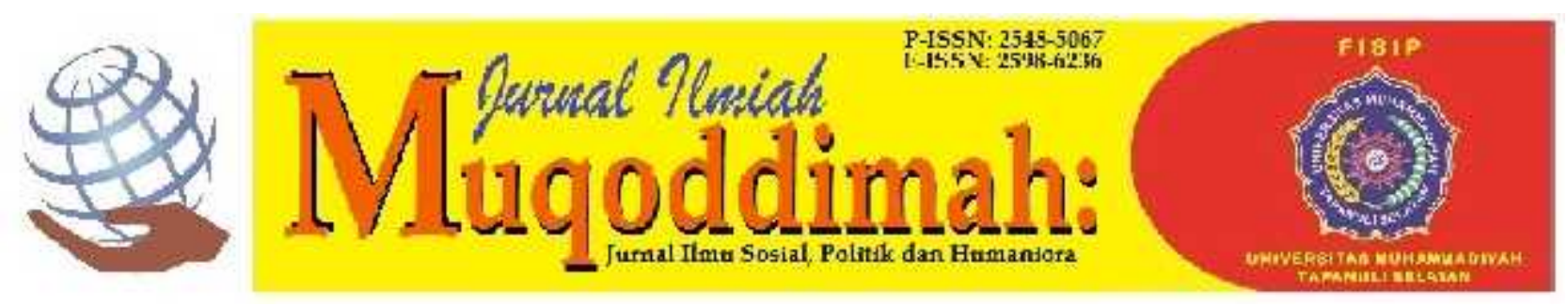

\title{
Political Leadership Transmission Practices by The Political Parties from 2006: A Study of Democracy in Bangladesh
}

\author{
Mohammad Eisa Ruhullah ${ }^{1)}$, Titin Purwaningsih ${ }^{2)}$ \\ Masters of the Government Affairs and Administration, Jusuf Kalla School of Government, \\ Universitas Muhammadiyah Yogyakarta, Indonesia \\ eisa.iium@gmail.com
}

\begin{abstract}
The is a summary of inquiry on democratic practices by the political parties on power transactions in Bangladesh since 2006. The research applied the qualitative descriptive method. This article aimed to measure the democratic process, power transmission, and the systematic crisis of the political parties with their wings. The examination found that the practices of parties are not purely democratic since the independence of the country. The government power is frequently gaining by two notable political parties in Bangladesh. The election commission is responsible for the fair election, but unfortunately, that is not independent. Moreover, the most significant issue is the distrust amongst authorities. That is why there are constitutional changes usually happen due to dishonesty under the dominant party. The Study refers to the amendment of the 15th constitutional practice, making the election system unfair because the election was happening while the current government still controls the systems. Thus, the country needs to have a non-dominant electoral mechanism or back to the amendment of the 13th old practices to make sure the democracy and transparency of the leadership in the country by the fair election. Hence, it will ensure the stability and the commitment of all bureaucrats to fulfill their services properly without control influence.
\end{abstract}

Keywords: Democracy; Political-crisis; Bangladesh; Dominant; Caretakergovernment.

\section{INTRODUCTION}

The present formation of student coalescence statesmanship in Bangladesh is sharply associated with racial statecraft. Bangladesh has four leading political bodies, namely Bangladesh Awami League, Bangladesh Nationalist Party, Bangladesh Jatiya Party, and Jamaat-e-Islam Bangladesh (Shah, 2016). All of them have a limb for students through student wings, especially government universities and other public, academic institutions (Huque \& Ferdous, 2019). The political contradict and cruelty are ordinary perpetration in the campus life of public, academic institutions (Hossain, Alam, \& Shahriar, 2014).

Citizens of Bangladesh are blindly putting hopes on political parties in the country. Furthermore, political leaders are putting their hopes on the party chairperson. Although, according to the law of the party, various leadership positions should be selected for the meetings of the parties, these meetings are not organized regularly, and the party president/chairperson is elected unopposed. Councilors delegate their powers to the party chief for the election of members of all other organizations, and that is not democratic at all 
JURNAL ILMIAH MUQODDIMAH:

Jurnal IImu Sosial, Politik Dan Humaniora

E-ISSN : 2598-6236

http://jurnal.um-tapsel.ac.id/index.php/muqoddimah
Political Leadership Transmission Practices by The Political

Parties from 2006: A Study of Democracy in Bangladesh

(Mohammad Eisa Ruhullah, Titin Purwaningsih)

(Amundsen Inge, Rounaq Jahan, 2020). This researcher is making a secondary resources study to find out the gaps/ problems above mentioned political crisis in Bangladesh, especially on democracy for power transmission practices by the political parties. The structural spaces of the nationalist school include the notion of scientific and diversity concerning geography, geographical diseases, rules of practice, and federal programs, positions, and attachmentsnationalist living within external structural space and autonomy (e.g., government and interested organizations), party support, and social roots (Amundsen, 2016). The first research question to be work on this study; How the political parties transforming their leadership?

In Bangladesh level due to the weak organization of electoral parties, weak internal democracy of political parties, strong centralization, and conventional informal decision-making are restrained by a limited quantity of group elites (ethnic groups) (M.M. Awal Hossain, 2015). Six symbols were utilized to determine the nation of the Republic of private political parties. Signs are guidance adoption, candidate designation, policymaking, social multifariousness of leadership, transparency and electoral accountability for electoral funding, and inter- and interparty intensity. The difficulties that parties have faced are highlighted. Moreover, steps are being advised to modify the effectiveness of the political groups (Jahan, 2014). And the second question of this research paper; Why is Bangladesh experiencing the political crisis from 2006 till now? The paper is also going to find out the problems on the caretaker government (CTG) taking power at the end of October 2006, after the expiry of the administration of the Bangladesh National Party in 2006-2008 (ICG, 2008). The BNP government has extended the age of retirement of the Chief Justice in an unconstitutional way by prejudice to the appointment of the head of the caretaker government. The CTG ruled the government for an interim 90 days before the election of the parliamentary (Khan, 2015). The political controversy began with the appointment of the foremost dissident, a role that has been replaced by that of President $\mathrm{Dr}$ lajuddin Ahmed (Undp, 2009).

The interior time did mark by vehement protests initiated by the Awami League, killed 40 civilians and beaten hundreds in the first month. The Bangladesh Nationalist Party (BNP) had it is own complaint about the system and the opponent (Khan, 2015). And third question of this study; How does democracy practices by the parties?

Bangladesh witnessed a democratic period from 1991 to 2006, but during this period, the system of governance also debated the opposition is for limited validity although the military again ruled Bangladesh from 2007 to 2008, but indirectly (Reza, 2013). In 2009, Bangladesh back to democratic governance, and the BAL seized power with great success. The BNP-led coalition has refused to accept the results and has complained of election engineering. The $\mathrm{BL}$ government has passed the Fifteenth Amendment to the Constitution, which in 2011 rejected the caretaker government system. As a result, the BNP-led opposition political parties boycotted the January 5, 2014, elections and the BL won unopposed with 153 votes. 300 Members of Parliament. (More than 50\%) most of whom were elected unopposed from the ruling BL. Voter turnout was low, and most polling stations were empty. The January 5, 2014, election has several significant consequences. The first and probably the tenth general election testified to the frustration of the voters due to the denial of any election. It destroys the people's confidence in their democratic right to vote. It will have the opportunity to elect their leaders by showing the citizens no fear and intimidation about citizen voting and at regular intervals (Moloy Saha, 2020) and (Md Jaynal Abedin, 2020). Thus, the researcher strengthens to the future researcher on the political crisis in Bangladesh to bring the solution of existing smooth power transmission problems in the political system. This can be used as a reference to make sure there will not be unfortunate political events such as 1/11 Caretaker government crisis in 2006- 2008 in Bangladesh political history. In the future make sure the fair election for with a clean transmission of the leadership in the government. 


\section{RESEARCH METHODS}

This study is a qualitative investigation that employs secondary data; qualitative descriptive (QD) is a pattern utilized in qualitative research for comprehensive studies, expressly measuring the related appearances. Qualitative designating (QD) is a broadly cited analysis culture. That has been described as essential and suitable study questions to determine who, what, How, and where situations/ adventures plus gathering shrewdness. While large quantities of data are being thronged and archived by researchers universally, the practicality of appropriating enduring data for research is intensifying more prevalent (Melissa $\mathrm{P}$. Johnston, 2014). That is why the author chose this method to complete this study. The main objective of this paper is to identify the transformation of leadership by political plotters and obstacles to the establishment of a republic in Bangladesh. The study then proposes a policy system to overcome these problems. Finally, the researcher has also briefly discussed the possibilities of a republic in Bangladesh. The article is collected in media sources such as books, journals, research reports and newspapers. Appropriate literature has also been accumulated through an internet browser like Google Scholars (M.M. Awal Hossain, 2015).

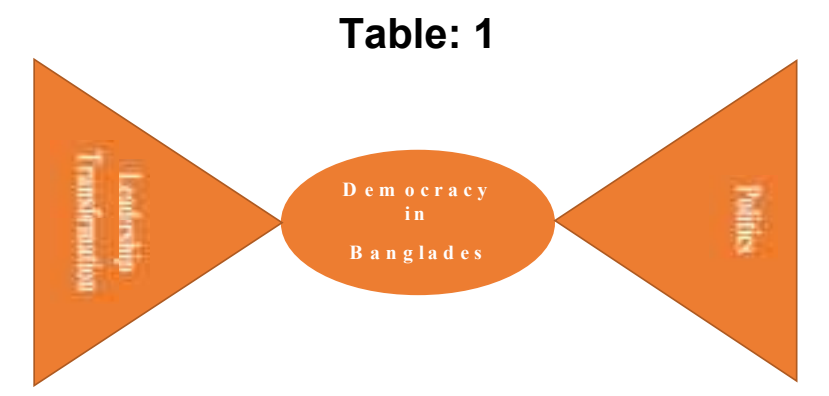

Source: Author Mohammad Eisa Ruhullah (2021)

Moreover, the researcher concentrates on practices of the leadership transformation amidst the political parties' democratization of the parties' leadership in Bangladesh politics. The investigation will determine the solution for those crises mentioned via the research problems, which are current issues in Bangladesh's political systems for future generations. The study will benefit future researchers and people who want to improve the traditional political practices to the modern ones in the country.

The political parties in Bangladesh with inheritance culture; the most famous party, the Bangladesh Awami League, known as the Awami League, dominated the scene. There is an expanse of political parties in the next 20 years, with 52 political parties contesting the 2001 general election. The significant rise of political groups strikes the country enjoys the spread of political liberalism even after the periodic suspension of the constitution, the ban on political activities and even the ban on political parties in the 1970s. The main political parties in contemporary Bangladesh are Awami League, BNP, Jamaat-e-Islami Bangladesh, and Jatiya Party. With its roots in the 1949s, Awami League has enjoyed the support of the oldest political party, especially the grassroots for its leadership role in the 1971 war of independence. The Awami League was in power from 1972-1975 and 1996-2000 (Rahman, 2010) and is currently in power from 2008-2020 (Khalid, 2019).

The late Army General-The late President Ziaur Rahman established the BNP in 1978 and has gained equal popularity as the Awami League. This party was in power during 19791983, 1991-1995 and 2001-2006. There are dozens of other small, personality-centered teams that collaborate with the big teams or in the shadow of grace. Further to these, many needles communist and socialist parties that represent the socialist ideology. However, the country has 
JURNAL ILMIAH MUQODDIMAH:

Jurnal IImu Sosial, Politik Dan Humaniora

E-ISSN : 2598-6236

http://jurnal.um-tapsel.ac.id/index.php/muqoddimah
Political Leadership Transmission Practices by The Political Parties from 2006: A Study of Democracy in Bangladesh (Mohammad Eisa Ruhullah, Titin Purwaningsih)

efficaciously ended today with a two-party system led by the Awami League and the BNP. After the overthrow of the military in 1990 through a joint movement of political parties, the Awami League or BNP formed a government. However, each time They formed the government in coalition with other political groups. Most of the political groups in pre-independence Bangladesh are at risk of communalism. Notwithstanding, there were purposes when opponent teams worked together to achieve specific national goals. For example, during the anti-Ershad democratic movement in the late 1980s, all political parties came under two broader alliances, the 14-party (Awami League-led) and the 15-party (BNP-led) (Fair, 2020).

The dream of democratic governance faced difficulties soon after its independence. The nation is involved in the inheritance of blood. Although it started with the Westminster model of democracy, in 1975 itself, Bangladesh took very little time to transform itself into a single-party system of government. Royal leader Sheikh Mujibur Rahman was brutally murdered by most of his family members by most army officers. The fall of the Ershad regime from 1975 to 1990 . The country was lagging in the military and civilian rule. In the five years of his reign, President Ziaur Rahman faced 20 uprisings and coup attempts; Twenty-one killed him. The cabinet was reshuffled 87 times between 1972 and 1992. This nine-year-long movement led to the fall of the Ershad government. The country was on the path to democracy again through the 1991 general elections (Maitrot \& Jackman, 2020).

Caretaker government versus political reforms with democratization by Bangladeshi political parties; According to Shukla (2019), in March 1996, under intense pressure from the Awami League-led opposition, the Khaleda Zia government made a Non-Political Caretaker Government NPCG a permanent feature of the electoral system by bringing in the thirteenth amendment to the constitution, but subsequent elections held under the NPCG brought the Awami League to power. Under the apex court's ruling, it later repealed the hedonism of the caretaker government in the 15th Constitution Amendment in 2011(Shukla, 2018). As stated by Rezwan (2019), emergencies imposed on the country prevent the state from active politics in 2006. However, there was talk at the party level for clear and political reforms in Bangladesh politics (from corruption) and for establishing democracy among the parties. It is happening under the guidance and patronage of people in emergencies situations (Rezwan, 2007).

According to Dasandi \& Esteve (2017), several reforms have been introduced to increase the accountability of bureaucrats. The response is the development of a symbolic relationship between politicians and bureaucrats. From a dominant point of view, the bureaucracy has shifted its position and aligned with other powerful groups in the system. It has increased the amount of bureaucratic politics that affects the functioning of critical elements of government (Dasandi \& Esteve, 2017). From the study of Amundsen, (2016) contains important issues related to the democratization of party politics and the possibility of consolidating democracy in Bangladesh. The enmity among the ruling alignment and the main opponency party, the tendency for violence, the complete disregard of the rule of regulation, the detrimental significant of parliament, the street protests and the growing religious militancy have all been affected (Amundsen, 2016). In Bangladesh, more than a decennium after the nation assign on a second journey towards forming a peaceful republic society, the events of 2004 had growth scrutinize about the future of democracy at nationally and internationally.

As stated by Moniruzzaman (2009), it is arguable that house of representatives failed to become a centrum of Political and legal activity. This is predominantly because the leading parties designedly bypass congress, while the opponent leaves it. The house of the representatives has been inactive almost half of its term. But, for a while, it was effective, its pursuit assembly adherent more to group political conflict than legal mobility. Parliamentary standing committees were less effective due to opposition boycotts, neglect of the ruling party and the absence of ordinary members and lacked parliamentary accountability of the 
JURNAL ILMIAH MUQODDIMAH:

Jurnal IImu Sosial, Politik Dan Humaniora

E-ISSN : 2598-6236

http://jurnal.um-tapsel.ac.id/index.php/muqoddimah
Political Leadership Transmission Practices by The Political Parties from 2006: A Study of Democracy in Bangladesh (Mohammad Eisa Ruhullah, Titin Purwaningsih)

government (Moniruzzaman, 2015). According to the research of Kabeer, Mahmud, \& Isaza Castro, (2010), Spreading the continuity between microorganisms and social cohesion, members of six organizations find that the specific development strategies of this membershipbased group have certainly had consequences for both development and democracy in the country. Promoting leadership among the politically organized citizens and women in Bangladesh, the short run is conducted by non-governmental organizations, and there is a desire for democratic practice at the local level (Kabeer et al., 2010).

As stated by UDDIN (2013), Women studying micro-credit companies in the region have suggested promoting political power or civic engagement because these companies fail to centralize and collect instalments in credit delivery services, and deviate or move away from community cohesion (UDDIN, 2013). According to Lewis (2017), the subject of this worldwide investigation: (1). An institutional setting that is dominated by a clientelist framework that attempts to create horizontal alliances between disadvantaged groups in decent society or weakens the connection among NGOs and political groups. (2). Address the location of companies in the defined field of the market from the consolidation of charitable leaders; And (3). The partitioning structures that have created satellite public capture, co-location and personal self-determination and accountability. It concludes with some brief descriptions of Bertha's original patterns (Lewis, 2017).

Following the statement of Jahan (2018), after the restoration of electoral democracy in 1991, there was initially a two-party dominant system (1991-2001) which was later converted into two electoral alliances led by two major parties. Currently, It seems like we have been back on a one-party dominant system from 2014 (Jahan, 2018) till now 2020. Therefore, Sheikh Hasina was now armed with the Supreme Court's decision to declare the 13th Amendment and, therefore, proclaimed the illegal non-party superintendent government (NPCG). Contrariwise, the leaders of the opposition BNP and the alliance took the position that they would not participate in any election without the NPCG system. The Awami League-dominated Jatiya Sangsad / Parliament passed the 15th Constitution Amendment Bill on June 30, 2011, after several changes, including the repeal of the disposition for holding national volitions under the NPCG amid fierce protests from the BNP-led opposition (Shanta, 2017). Even Election Commission Mahbub Talukder said that, "he does not think there is fair play inside the Election Commission itself and the space for free speech in commission meetings has been gradually shrinking" at the commission office in Dhaka on Sunday, January 26, 2020 (Mamun Abdullah, 2020).

Political leadership transmission practices by the political groups in Bangladesh; The words of Amundsen (2016), the families themselves have been in power among the group, and different groups favor an undebated leadership. Moreover, royal politics is a proficient system of branding and vote-winning in a state where party programs are unclear, and civil favor "influential families" when elective. One of the outcomes of the dynastic contemplation in Bangladesh was the succession of a different shrewd climate, where two stirps fought in a stalemate. Another result of royal politics is the low dimension of interior party democracy. Bangladesh experiencing the party chairperson that rule their parties for more than 30 years and how they have been re-selected unchanged. In the case of the top leadership election, internal party democracy is not open to the democratic process, and essential decisions in formulating programs and forming alliances are the sole prerogative of the party leader and the internal circle (Amundsen, 2016).

The party president of the Awami League Sheikh Hasina and the Bangladesh Nationalist Party's Khaleda Zia are the daughters and widows of the founder of Bangladesh and one of the commanders of freedom fighters, respectively. Reported by the BRAC, on 'State Administration in Bangladesh' states: 'The inner circumambulate of the leading party gives an effective direct to 
JURNAL ILMIAH MUQODDIMAH:

Jurnal IImu Sosial, Politik Dan Humaniora

E-ISSN : 2598-6236

http://jurnal.um-tapsel.ac.id/index.php/muqoddimah
Political Leadership Transmission Practices by The Political Parties from 2006: A Study of Democracy in Bangladesh (Mohammad Eisa Ruhullah, Titin Purwaningsih)

the continuous party, the Cortes, house of the representatives' committees, derivative policy, improvement allocation, officialdom, and regulation enforcement.' Rehman Sobhan, Stanley Kochanek, and among others, have expressed mutual regard about the monopoly of political power by party leaders and those in power. According to most spectators, one of the primary contentions behind the breakdown of democracy (Khan, 2020).

In Bangladesh is the assiduousness of capacity in the hands of the party superintendence preferably than the status and archives of the political party. Although the concentrate of ability in the hands of the political superintendence is one of the slamming raised contra republic and administration in Bangladesh, another area of regard among rubberneck is the regulation of political professors in perpetuate power in favor of political groups. The activities of political parties in rural Bangladesh have given rise to new types of violence at the local and national levels.' The role of local level party organizers and political inspiration Political parties are essential in Bangladesh. These intermediaries are responsible for systematize, consolidating and enforcing violence on behalf of political parties at the local level and, if necessary, for the formation and consolidation of their followers at the national level. The degree and ability of the organization to organize is a key determinant of political strength and electoral success. The institution and combination of the party by the mid-level political zeal leads to a nationalistic loyalty among the party superintendence and the local-level politicians (Khan, 2020).

Although the unparalleled rewards of transactional leadership and ideological impact and the unique deliberation of transformational leadership has had a significant and positive impact on the growth of organizational schooling, the results of this study reflect organizational learning as a dimension of transformational leadership style as well as transactional leadership. Furthermore, it was not reported any important impact of prescription by management (Uddin, Khan, \& Ali, 2017).

Furthermore, the significant electoral parties put on paper a broad organizational structure at the state level and sub-national levels, the party machinery usually becomes almost active during elections. To seize power through the electoral process, parties often collaborate with influential local leaders who control the vote or are considered "elected." These co-led leaders are generally moving faster in the party hierarchy than older and loyal party workers. Even the tradition of the A-League tended to have the same organizational presence as the grassroots (Jahan, 2018).

Another interesting way to select Bangladeshi leaders is that posters can be considered a practical element in a wide range of party politics networks. Bangladesh's political posters are more than just a political message for election victory. Instead, they are needed to 'compose, maintain, and assemble' inter-party statecraft. Political placards emerged as a significant tool in the social politics of Bangladesh in terms of power, political performance, and socio-economic perception of space. These placards mediate inter-party competitiveness over opportunities and dominance and how inter-party caliber relations are structured (Kuttig, 2020).

\section{RESULTS AND DISCUSSION:}

The political reforms with democratization by Bangladeshi political parties; Bangladesh is a homogeneous country with some cracks in terms of ethnicity, religion, or caste. People historically have expressed keen democratic consciousness. So, the case in Bangladesh is shocking and is of more academic interest than the case. This literature reviewed to analyze the theoretical basis of a process that keeps the country suspended in liberal democracy and prevents democratic integration from focusing on the reality of everyday minor conflicts between political parties and the test of the enemy's speech. In this example, there is political violence; observers attribute a motif of electoral ferocity in different related reasons country. Such is the 
JURNAL ILMIAH MUQODDIMAH:

Jurnal IImu Sosial, Politik Dan Humaniora

E-ISSN : 2598-6236

http://jurnal.um-tapsel.ac.id/index.php/muqoddimah
Political Leadership Transmission Practices by The Political Parties from 2006: A Study of Democracy in Bangladesh (Mohammad Eisa Ruhullah, Titin Purwaningsih)

antiquity of intense competition within political groups, a broad culture of free competition and violence for government positions that carry power and state expansion. Plenty and often used. The strong politicians often have their own armies, and some members of the security forces were also working to protect or serve political officials, police said. Although no single theory can inculpate all the inseminate causes of electoral rampancy, some elements criticize all three elements: republication or political change, where savagery occurs, the impact of elections on the pace of conflict, and nature and political implications.

A critical improvement took place from 1991- 2006 on the vigil of the transplant of authority to the interim supremacy in Bangladesh. Retired Chief Justice Nominee, former Chief Justice KM Hassan has ignored to accept the post due to widespread ferocity in the country. The letter was received by the President on October 27, 2006, rejecting Justice KM Hasan's job offer. After that, the President had an assembly with BNP Secretary General Abdul Mannan Bhuiyan and Awami League General Secretary Abdul Jalil and introduced himself as the Chief Adviser. Then the President said, on October 29, lajuddin Ahmed took over as President and Chief Adviser to the non-partisan superintendent government. However, after an emergency assemblage with the 14-party leader at her apartment in the capital in November 2006, Awami League $(A L)$ president Sheikh Hasina said there were "questions about the president's neutrality" and wanted to remove him. The position of chief adviser to the non-party caretaker government.

As political tensions thicken, Bangladeshi President lajuddin Ahmed declared a state of emergency on 12 January 200. He abandoned as head of the caretaker government during the general election. He will, of course, remain president. He also obstructed the election from January 22 to an unmarked date. Lately, had election the victory owns by the Awami League party with majority seats from the 300 plus 45 women seats. Furthermore, it took place in the government, which is still today they are in power. It is complicated to say that the current government is practicing a democratic system or dictatorship system. Current government because it seems they came to power; the electoral system has been changed with a new law constitutional amendment 15th. That is what Bangladesh's political situation.

However, the political crisis continues until nowhere. This table shows that a dramatic declined in members of parliament due to the boycott of the election by the opposition party BNP and it is members parties.

Figure: 1 Quantity of the Opposition Party's Members in the National Parliament/Jatiya Sangsad (1991-2014)

\begin{tabular}{lc}
\hline National Parliament (Jatiya Sangsad) & $\begin{array}{c}\text { Number of the Opposition Members of } \\
\text { Parliament in the Parliament (Sangsad) }\end{array}$ \\
\hline 1991- ( $5^{\text {th }}$ Sangsad/ Parliament) & 147 \\
$1996-\left(7^{\text {th }}\right.$ Sangsad/ Parliament) & 120 \\
2001- ( $8^{\text {th }}$ Sangsad/ Parliament) & 77 \\
2008- ( $9^{\text {th }}$ Sangsad/ Parliament) & 34 \\
2014- $\left(10^{\text {th }}\right.$ Sangsad/ Parliament) & 33 \\
\hline
\end{tabular}

Sources: (Shanta, 2017)

Because of the opposition boycott, the EU, the United States, the Commonwealth, and the Russian Federation refused to observe the parliamentary elections. They all appealed for inclusive and participatory polls. The New York Times called the vote a "bizarre election" due to a lack of competition. UN Secretary-General Ban Ki-moon has called on political groups to engage in consequential dialogue. The Commonwealth, a voluntary organization of 53 independent countries, has called the 10th parliamentary elections "disappointing" in 
JURNAL ILMIAH MUQODDIMAH:

Jurnal IImu Sosial, Politik Dan Humaniora

E-ISSN : 2598-6236

http://jurnal.um-tapsel.ac.id/index.php/muqoddimah
Political Leadership Transmission Practices by The Political Parties from 2006: A Study of Democracy in Bangladesh (Mohammad Eisa Ruhullah, Titin Purwaningsih)

Bangladesh. "The UK believes that the key to a mature, functioning democracy is a peaceful, credible election that reflects the real will of the electorate," commented Foreign Secretary Barnes Warsi. Voters do not have the opportunity to express their will at the ballot box and in most other constituencies with very few voters. Although most of the international community has expressed frustration over the elections, India has shown a different view that the elections held on January 5 were a constitutional requirement and were a matter of internal and lawful process in Bangladesh (Shanta, 2017).

Political leadership transmission in Bangladesh; the dynamic mentality of political leaders combined with the art of auspice and fascinating law has led to the flop of inside democracy between partisan groups and the mutual harmony of party organs. Superintendence statuses have nevermore confronted, and even in general elections, the parties have faced defeat. This command to a complete centralization of potency in the hands of the direction. Rahman noted that "there is no precedent in our recent political history for any of the leaders of these two parties to dare to oppose any proposal or decision of their leader." They (chiefs) have remained the primary source of capability in their groups. The labyrinth of the political diagnostic of Bangladesh is the faith of the sceptred political leaders about the right to the royal and their view that the antithesis has no verifiable right in politics. Sheikh Hasina, the daughter of Sheikh Mujib and Khaleda Zia, the widow of Ziaur Rahman, questions the legitimateness of the existence of the other, as discussed above, let her play a preamble in politics.

Furthermore, the Bangladesh Awami League (BAL) and the Bangladesh Nationalist Party (BNP), distinguished by a lack of central republic, have a highly amalgamated and personalized interior governance design close to the authentic power of the party chairperson. The most recognized reasons for the intentness of power within the internal circles of political parties are the two main political parties. They are due to being dynastic (who have generally brought alternative power since 1991 before the 2014 elections). The election of local politicians who have decided to become a party at the national level and have helped organize low-level gangs (gangs for violence) has become necessary. It is ordinarily accepted by laical society and the ostensible that all political groups have their armed cadres. The liability of these cadres is to continue and intensify the partisan basis of the political group concerned and to deal with the nuclei of the emulate parties. This nucleus means that politics has become increasingly dependent on muscle power. With money and armed support, a new species of 'politicians' is increasingly replacing senior politicians in control among the combination based on their strength and loyalty to assignment for the party.

Moreover, increasing the reliance of political groups on mid-level trailblazer and the powerful, there is still an idea that the absolute power is in the medium of the leadership. An investigation of why the Awami League elected Shamim Osman as the Awami Leagueapproved mayoral candidature in Narayanganj in 2011 shows that increasing reliance on politically powerful people by political groups means that interrogate from middle-level planter are increasingly crucial to the party leadership. Reliable and free to make unilateral decisions. The ability to organize, organize, and create violence in the hands of mid-level organizers gives them high strength and power. Thus, power is distributed in a fixed manner between the middle and lower peaks of the political party, empowering local party leaders. They can also act as the party's 'muscle' organizer, and exempting other grassroots workers, ameliorating undemocratic practices within Bangladesh.

Additionally, political groups in Bangladesh remain highly consolidated, and decisionmaking sovereignty, especially in the case of critical electoral determination such as the nomination of candidates, remains in the hands of the party leader and his close advisers. Leading political groups, election spectators, and non-governmental organizations (NGOs) involved in the election. The researchers found that most people believed that dynasty and 
JURNAL ILMIAH MUQODDIMAH:

Jurnal IImu Sosial, Politik Dan Humaniora

E-ISSN : 2598-6236

http://jurnal.um-tapsel.ac.id/index.php/muqoddimah
Political Leadership Transmission Practices by The Political Parties from 2006: A Study of Democracy in Bangladesh

(Mohammad Eisa Ruhullah, Titin Purwaningsih)

patronage connections in the form of muscle or money were crucial for nominations from chiefs-political parties and electoral power ultimately go-to party leaders. The nomination process is utterly rotten. It is not a party, and it is an individual. No party, one person and a small court do not exist as a party that controls a syndicate through money. And of course, money also gets muscle strength. They said that the person would be nominated in negotiation with the local level through the reforms of the last election (reforming the caretaker government of 2007-2008). However, it does not matter due to politics. They were paying for nominations and paying people to vote for you.

In Bangladesh, party commanders must be elected at adjustable party conferences or conferences according to the rules prescribed by party rules. In the case of both the Awami League and the BNP. The election of leadership, including the selection of party leaders, was conducted in advance, and was only formally approved by the Convention. Officially, the president and general secretary of the A-League are elected through a three-year party conference known as the Council, the party's highest body. The Council is made up of 30004000 district representatives, including the president, general secretary, and about 25 party members from the party's 74 district bodies (Amundsen, 2016). Then, the Triennial Council elects a majority member to elect other party bodies where the party president nominates a specific number. When it comes to the nomination of party candidates for the parliamentary elections, the Awami League, like some other parties (including the BNP), is increasingly 'selling'. 'You can now buy a plane ticket to Singapore and nominate yourself as an MP: you go and leave!' Said a Bangladeshi MP, referring to the practice.

Moreover, administrative reproduces in Bangladesh have slipped to achieve their goals because of the dominance of clericalist interests in the public benefit. The wisdom highlights the significance of checking and balancing the role and impact of bureaucratic superintendence in the structure and implementation of cabbalistic legislative reforms. Another funniest way to select the leaders in Bangladesh is, Posters can be considered as a practical element in the extensive networks of party politics. Bangladesh's political posters are more than just conveying federal messages for election triumph. Alternatively, they are an element to the 'configuration, sustenance, and assembly' of inter- and inter-party campaigning. Partisan posters surfaced as an essential device in the social politics of Bangladesh in terms of power, political performance, and socio-economic perception of space. Through these advertisements, inter-party disputes over space and prestige are arbitrated and how inter-party power connections are structured.

\section{CONCLUSION:}

The answer to the research question one that, it is difficult to reconcile the feudal foundations of Bangladeshi politics, its historical lack of democratic institutionalism, and the related pathological issues that characterize the country's political upheaval. The corollary of the pathology of Bangladeshi politics is the belief in the rights of the ruling political leaders and their belief that the opposition has no legitimate rights in politics. Sheikh Hasina, the daughter of founder father of Bangladesh Sheikh Mujib and Khaleda Zia, the widow of Ziaur Rahman, questioned the validity of the existence of the other, as discussed above, let us play a role in politics. That is why, Bangladesh's constitutional amendments have been used in a materialistic way for political success which in turn gives the ruling party an electoral advantage (Khan, 2015).

It can be answer to the second question of this study that, democratic institutions and institutions of accountability have used successive governments to pass constitutional amendments that favor the ruling party. The article addresses the Special Committee's report on the Fifteenth Amendment and the Supreme Court's 13th Amendment judgment, which declared the caretaker government's provision unconstitutional and therefore gave the government the 
JURNAL ILMIAH MUQODDIMAH:

Jurnal IImu Sosial, Politik Dan Humaniora

E-ISSN : 2598-6236

http://jurnal.um-tapsel.ac.id/index.php/muqoddimah
Political Leadership Transmission Practices by The Political Parties from 2006: A Study of Democracy in Bangladesh (Mohammad Eisa Ruhullah, Titin Purwaningsih)

necessary legality to amend the constitution. The study of constitutional amendments concerning the provision of non-political caretaker government also illustrates how political parties have demanded or rejected constitutional amendments, depending on the government or the opposition. The Eleventh Parliamentary Election of Bangladesh will be held in NovemberDecember 2018 year (Md Jaynal Abedin, 2020).

As in the past, the election is expected to be held through various debates, some new and some permanent. Once again, ensuring free and fair elections in a highly divisive, politicized, and non-violent environment. Bangladesh, as in the past, is going to be a big challenge for the state. Begum Khaleda Zia, head of the main opposition Bangladesh Nationalist Party (BNP), is in jail on corruption charges after she was not released before the election. The leaderless BNP has threatened to boycott the upcoming elections if he is not released, and the neutral or non-partisan caretaker government (NPCG) is not conducted (BBC, 2014). The BNP boycotted the 2014 elections (Ellen Barry, 2014), saying it had no faith in the electoral process in the absence of a non-partisan caretaker government (NPCG) (Lorch, 2019). Although the boycott resulted in only $30 \%$ of the electorate voting, the Awami League (AL) came to power with an overwhelming majority (Kamran Reza Chowdhury, 2020). It won 150 seats unopposed (Balachandran, 2018).

The research question number three's answer can be said that, since independence, however, our achievements in democracy and development have not been remarkable. Every political leader or party in Bangladesh, citizen, or military, popular or unpopular, big, or small, out of power or out, spoke incessantly about democracy. Nevertheless, the nation has failed to implement it. Taking advantage of this situation, the military leaders intervened to practice their version of democracy, which only exacerbated the crisis. The country today is puzzled by the myriad problems that threaten the very development of democracy. Our society lacks a developed political culture and a poverty-stricken illiterate, and incompetent people without democratic political organizations, institutions, and practices (M.M. Awal Hossain, 2015).

Moreover, this is true that Bangladesh is not having pure political democracy in party leadership and election in 2014 and 2018 mostly; it is one major-party system with a dominant by the current government. Thus, the 15th amendment of the constitution necessity to be practiced without dominant from the government to election commission (EC) to hold the election in the free mood to ensure the fair result of the national election. Bangladesh obliges political factions that can incorporate, train, and train people in republic values, policies, and methods preferably than endless political disguise and conflict. Bangladesh requires, including politics and party-internal democratic systems that create more legitimate and proficient policy programs. It can give a broad social representation and is limited to acknowledging the right to party leadership. Bangladesh needs political groups that can subscribe to establishing democratic cultivation by becoming an internal democracy.

\section{ACKNOWLEDGEMENT:}

This research is an assessment during my master's degree studies. At the Department of Government Affairs and Administration at Universitas Muhammadiyah Yogyakarta to make journal publications. I humbly thank my lecturer, Associate Professor Dr. Titin Purwaningsih, for inspiring me to make this study a paper publication.

\section{REFERENCES}

Amundsen, I. (2016). Democratic dynasties? Internal party democracy in Bangladesh. Party Politics, 22(1), 49-58. https://doi.org/10.1177/1354068813511378

Amundsen Inge, Rounaq Jahan, H. (2020). The Political Parties in Bangladesh : Political Dynasties and Democratisation. In https://www.cmi.no/projects/1436-the-political-parties-in- 
bangladesh.

Balachandran, B. P. K. (2018). Ensuring free and fair polls, a challenging task in. MENAFN.COM, pp. 1-6.

BBC. (2014). Bangladesh profile - Overview. BBC News Asia, pp. 1-3. Retrieved from http://www.bbc.co.uk/news/world-south-asia-12650942

Dasandi, N., \& Esteve, M. (2017). The Politics-Bureaucracy Interface in Developing Countries. Public Administration and Development, 37(4), 231-245. https://doi.org/10.1002/pad.1793

Ellen Barry. (2014). Bangladesh's Governing Party Wins Vote Amid Unrest. The New York Times, pp. 7-8.

Fair, C. C. (2020). Bangladesh in 2019. Asian Survey, 60(1), 189-195. https://doi.org/10.1525/as.2020.60.1.189

Hossain, M. M., Alam, M. M., \& Shahriar, S. M. (2014). Students' Perceptions Study on "Student Politics" in Bangladesh. International Journal of Economics and Empirical Research, 2(1), 1-6.

Huque, A. S., \& Ferdous, J. (2019). Bureaucratic and political leadership in Bangladesh: dynamics of administrative reform and the public interest. Asia Pacific Journal of Public Administration, 41(3), 169-180. https://doi.org/10.1080/23276665.2019.1658364

ICG. (2008). Restoring Democracy in Bangladesh. In 6/12/2020 Restoring Democracy in Bangladesh | Crisis Group a u e to egot ate wou d $v$ te co o tat o. Stude $t$ u est August 2007 showed how quickly frustration with military rule can boil over. Two floods, a devastating cyclone and rising food prices have I. Retrieved from http://www.crisisgroup.org/ /media/Files/asia/southasia/bangladesh/151_restoring_democracy_in_bangladesh.pdf

Jahan, R. (2014). Political Parties in Bangladesh. Centre for Policy Dialogue. Retrieved from https://www.cmi.no/publications/file/5229-political-parties-in-bangladesh.pdf

Jahan, R. (2018). Political Parties Movements, Elections and Democracy in Bangladesh.

Kabeer, N., Mahmud, S., \& Isaza Castro, J. G. (2010). NGOs' Strategies and the Challenge of Development and Democracy in Bangladesh. IDS Working Papers, 2010(343), 01-71. https://doi.org/10.1111/j.2040-0209.2010.00343_2.x

Kamran Reza Chowdhury. (2020). Bangladesh : Dhaka Elections Not Fair , Opposition Complains. BenarNews, pp. 4-6.

Khalid, S. (2019). Hasina wins Bangladesh elections as opposition rejects polls. Al Jazeera News, 1-3. Retrieved from https://www.aljazeera.com/news/2018/12/hasina-takes-earlylead-deadly-bangladesh-election-day-181230135104803.html

Khan, A. A. (2015). The politics of constitutional amendments in Bangladesh: The case of the non-political caretaker government. International Review of Law, 2015(3), 9. https://doi.org/10.5339/irl.2015.9

Khan, A. A. (2020). Power, patronage, and the candidate-nomination process: Observations from Bangladesh. Modern Asian Studies, 54(1), 314-336. https://doi.org/10.1017/S0026749XI80000239

Kuttig, J. (2020). Posters, politics, and power : mediated materialisation of public authority in Bangladesh party politics. South Asia-Journal of South Asian Studies, 43(6), 1-2.

Lewis, D. (2017). Organising and Representing the Poor in a Clientelistic Democracy: the Decline of Radical NGOs in Bangladesh. Journal of Development Studies, 53(10), 15451567. https://doi.org/10.1080/00220388.2017.1279732

Lorch, J. (2019). Islamization by Secular Ruling Parties: The Case of Bangladesh. Politics and Religion, 12(2), 257-282. https://doi.org/10.1017/S1755048318000573

M.M. Awal Hossain. (2015). Democracy in Bangladesh : Problems \& Prospects. (October).

Maitrot, M., \& Jackman, D. (2020). ESID Working Paper No . 132 The 2018 Bangladeshi election. Effective States and Inclusive Development Research Centre (ESID), (132), 1-25.

Mamun Abdullah. (2020). Mahbub Talukder: No fair play within EC itself He urged the 
commission to not consider him a minority, but rather to consider the merit of his statements. Dhaka Tribune, pp. 1-2.

Md Jaynal Abedin. (2020). LEGITIMACY CRISIS IN BANGLADESH : A CASE STUDY OF 10 th GENERAL ELECTION. European Journal of Political Science Studies, 3(2), 1-19. https://doi.org/10.5281/zenodo.3612187

Melissa P. Johnston. (2014). Secondary Data Analysis: A Method of which the Time Has Come. Qualitative and Quantitative Methods in Libraries (QQML), 49(1-2), 24-30. https://doi.org/10.1159/000479695

Moloy Saha. (2020). No fair election possible under this govt: parties. New Age, pp. 1-2.

Moniruzzaman, M. (2015). Parliamentary democracy in Bangladesh: An evaluation of the parliament during 1991-2006. Commonwealth and Comparative Politics, 47(1), 100-126. https://doi.org/10.1080/14662040802659017

Rahman, S. (2010). Institutionalization of Democracy in the Political Parties in Bangladesh. North, 89. Retrieved from http://mppg-nsu.org/attachments/119_Institutionalization of democracy, by Saidur [final].pdf

Reza, A. (2013). Democracy in Bangladesh : A Report Card. South Asia Jounal, (June 2012), 1-8.

Rezwan. (2007). Bangladesh : Political reforms. Global Voices, pp. 5-6.

Shah, A. (2016). Democracy deadlocked in Bangladesh. Current History, 115(780), 130-135.

Shanta, H. A. (2017). The Caretaker Debate, 10th Jatiya Sangsad Elections and Recent Trends in Bangladesh Politics. South Asian Studies, 32(2), 523.

Shukla, A. (2018). BNP' s Narrowing Options in Bangladesh. Www.Icwa.In, 1-5. Retrieved from $\% 0 A w w w . i c w a . i n$

UDDIN, M. J. (2013). Microcredit, Civic Networks and Women'S Political Involvement in Bangladesh. The Hong Kong Journal of Social Work, 47(01n02), 3-18. https://doi.org/10.1142/s021924621300003x

Uddin, M. M., Khan, M. A., \& Ali, K. (2017). Role of leadership on organizational learning in private universities of Bangladesh. IIUC Studies, 14(2), 9-34. https://doi.org/10.3329/iiucs.v14i2.39878

Undp. (2009). Elections and conflict prevention. Democratic Governance Group Bureau for Development Policy. 